\title{
Ecological Risk Indicators for Leached Heavy Metals from Coal Ash Generated at a Malaysian Power Plant
}

\author{
Teh Sabariah Binti Abd Manan 1,*D, Salmia Beddu 2,*, Nur Liyana Mohd Kamal 2 , Daud Mohamad ${ }^{2}$, \\ Zarina Itam ${ }^{2}$, Taimur Khan ${ }^{3}(\mathbb{D})$, Affiani Machmudah ${ }^{4}$, Denys Dutykh ${ }^{5}$ D, Wan Hanna Melini Wan Mohtar ${ }^{6} \mathbb{D D}$ \\ Hisyam Jusoh ${ }^{7}$, Fadzli Mohamed Nazri ${ }^{8}\left(\mathbb{D}\right.$, Md Fauzan Kamal Mohd Yapandi 9,10 ${ }^{\mathbb{D}}$, Siddhartha Pati ${ }^{11,12} \mathbb{D}$, \\ Amirrudin Ahmad ${ }^{1,13}$ and Nadiah Wan Rasdi 1,14
}

Citation: Abd Manan, T.S.B.; Beddu, S.; Mohd Kamal, N.L.; Mohamad, D.; Itam, Z.; Khan, T.; Machmudah, A.; Dutykh, D.; Mohtar, W.H.M.W.; Jusoh, H.; et al. Ecological Risk Indicators for Leached Heavy Metals from Coal Ash Generated at a Malaysian Power Plant. Sustainability 2021, 13, 10222. https://doi.org/10.3390/su131810222

Academic Editors: Tony

Robert Walker and Elena

Cristina Rada

Received: 26 June 2021

Accepted: 3 September 2021

Published: 13 September 2021

Publisher's Note: MDPI stays neutral with regard to jurisdictional claims in published maps and institutional affiliations.

Copyright: (c) 2021 by the authors. Licensee MDPI, Basel, Switzerland. This article is an open access article distributed under the terms and conditions of the Creative Commons Attribution (CC BY) license (https:/ / creativecommons.org/licenses/by/ $4.0 /$ )
1 Institute of Tropical Biodiversity and Sustainable Development, Universiti Malaysia Terengganu, Kuala Nerus 21030, Terengganu Darul Iman, Malaysia; amirrudin@umt.edu.my (A.A.); nadiah.rasdi@umt.edu.my (N.W.R.)

2 Department of Civil Engineering, Universiti Tenaga Nasional, Jalan Ikram-Uniten, Kajang 43000, Selangor Darul Ehsan, Malaysia; Yana_Kamal@uniten.edu.my (N.L.M.K.); Daud@uniten.edu.my (D.M.); iZarina@uniten.edu.my (Z.I.)

3 Civil and Environmental Engineering Department, Universiti Teknologi PETRONAS, Seri Iskandar 32610, Perak Darul Ridzuan, Malaysia; taimurkhan7@gmail.com

4 Industrial Engineering, Faculty of Advanced Technology and Multidisciplinary, Universitas Airlangga, Jalan Mulyorejo, Kampus C, Surabaya 60115, Indonesia; affiani.machmudah@stmm.unair.ac.id

5 Univ. Grenoble Alpes, Univ. Savoie Mont Blanc, CNRS, LAMA, 73000 Chambéry, France; Denys.Dutykh@univ-smb.fr

6 Civil Engineering Department, Faculty of Engineering and Built Environment, Universiti Kebangsaan Malaysia, Bangi 43600, Selangor Darul Ehsan, Malaysia; hanna@ukm.edu.my

7 Geo TriTech, No. 17, Persiaran Perdana 15A, Pinji Perdana, Lahat 31500, Perak Darul Ridzuan, Malaysia; mnhisyam.jusoh@gmail.com

8 School of Civil Engineering, Engineering Campus, Universiti Sains Malaysia, Nibong Tebal 14300, Penang, Malaysia; cefmn@usm.my

9 TNB Research Sdn. Bhd. No. 1, Kawasan Institusi Penyelidikan, Jalan Ayer Itam, Kajang 43000, Selangor Darul Ehsan, Malaysia; fauzankamal@tnb.com.my

10 Faculty of Applied Science, Universiti Teknologi Mara, Shah Alam 40450, Selangor Darul Ehsan, Malaysia

11 SIAN Institute, Association for Biodiversity Conservation and Research (ABC), Balasore 756001, Odisha, India; patisiddhartha@gmail.com

12 Department of Biotechnology, Academy of Management and Information Technology, Khordha 752057, Odisha, India

13 Faculty of Science and Marine Environment, Universiti Malaysia Terengganu, Kuala Nerus 21030, Terengganu Darul Iman, Malaysia

14 Faculty of Fisheries and Food Science, Universiti Malaysia Terengganu, Kuala Nerus 21030, Terengganu Darul Iman, Malaysia

* Correspondence: tehsabariah@umt.edu.my (T.S.B.A.M.); Salmia@uniten.edu.my (S.B.); Tel.: +60-3-89212020 (ext. 6219) (S.B.)

Abstract: The application of coal ash (CA) in construction industries has grown rapidly, posing risk to the environment due to heavy metals leaching from the material. This research presents a simulation of ecological risk assessment and model risk indicators (ERI) of leached heavy metals (lead $(\mathrm{Pb})$, copper $(\mathrm{Cu})$, zinc $(\mathrm{Zn})$ and arsenic (As)) from CA (FA: fly ash and BA: bottom ash) via response surface methodology (RSM). The ERI values were based on quantified leached heavy metals from the toxicity characteristic leaching procedure (TCLP-1311) and synthetic precipitation leaching procedure (SPLP-1312). The ecological risk index $\left(R_{I}\right)$ values for TCLP were $10.27 \times 10^{0}(\mathrm{FA}), 9.91 \times 10^{0}(\mathrm{BA})$ and $12.58 \times 10^{0}(\mathrm{FA}+\mathrm{BA})$; whereas $R_{I}$ for SPLP were $10.34 \times 10^{0}(\mathrm{FA}), 9.90 \times 10^{0}(\mathrm{BA})$ and $12.61 \times 10^{0}(\mathrm{FA}+\mathrm{BA})$. Twenty-nine combinations of operations were evaluated based on BoxBehnken design with ERI as the response variable. The established model risk indicator (i.e., coded and actual factors) of $\mathrm{Pb}, \mathrm{Cu}, \mathrm{Zn}$ and 'As' showed significant model terms that describe their relationship very well, perfectly fit to the corresponding ERI (sum of squares $=0.4160, \mathrm{~F}$ value $=$ $682,375.55$ ) with probability of $0.01 \%$ for an F-value could occur due to noise. The optimized models were validated with error percentage of less than $5 \%$. The established ERI models showed significant model terms and will be useful for ecological monitoring of CA application in construction industries. 
Keywords: coal ash; power plant; heavy metals; ecological risk indicators; ecological risk assessment; Box-Behnken design

\section{Introduction}

Coal is a geofuel for electric power generation that produces millions of tonnes of CA (i.e., FA and BA) as a by-product of the process [1]. ' $\mathrm{CA}^{\prime}$ ' has the potential to be sustainably reused, promoting green-coal ash technology, and reducing greenhouse gas emissions [2]. The waste should be managed without risking the environment (i.e., water, air, soil, plants, and animals) and human health [3]. Nevertheless, CA contains heavy metals and in the absence of proper waste management, it is a hazardous waste material that poses risk to both the environment and human health [4]. Heavy metals have atomic numbers greater than 20 with relatively high densities and are present in soils at low concentration. However, concrete mixes containing coal ash as a binder may pose risk of leaching heavy metals to the soil leading to adverse environmental and health impacts. The biohazards of heavy metals are due to their bioproperties, such as high toxicity with possibilities of acute and chronic toxicity effects [3,5-7]. Heavy metals are non-biodegradable metal ions that bioaccumulate in living organisms $[8,9]$. They can deteriorate brain and central nervous system, alter the blood composition, and corrode other vital organs $[7,10,11]$.

There are many recycled products made from CA such as radionuclide stabilizers in roadway pavements [12], adsorbents [13] and coagulants for wastewater treatment [14]. Moreover, it is useful as cement replacement material [15], good for brick production [16] and convenient as aggregate for concrete made from the combination of granite waste and FA [17]. ' $\mathrm{CA}^{\prime}$ ' is also rich in heavy metals making it a premium source for aluminium extraction $[14,18,19]$ as well as a source of rare earth metallic elements (e.g., yttrium, scandium, and 14 elements of the lanthanide series) [1,20-22]. It can also function as an excellent scrubber and fixation reagent for hazardous acidic sludge wastes containing toxic trace elements from the phosphate industry [17]. The reuse of CA as cement replacement material has been long established in the US construction industry [23,24]. FA consists of fine coal ash particles that accumulate in electrostatic precipitators or fabric filter baghouses. Meanwhile, BA consists of coarse granular particles that accumulate at the furnace's bottom $[23,25]$. These pozzolans are similar in heavy metals composition $[3,10,11,26]$.

Aquatic organisms (algae, plants, microbes, planktons, crustacean, fish etc.) are biological indicators of water pollution [27-29]. Ecological risk assessment studies are based on toxicity risk of a pollutant to aquatic organisms. It is essential in the current study to determine the risk posed to aquatic organisms by contaminants leached from coal ash like heavy metals. A good study model in this case is the application of microphyte plants of the Lemna genus for the bioremediation of wastewater [30].

Literature reports leaching studies focused on sulphate [31], single heavy metals such as mercury $(\mathrm{Hg})$ [32] or a combination of heavy metals [31,33-35], ammonia [36] and a combination of heavy metals and trace elements [37]. Researchers used standard procedures known as US EPA method 3501A (SW 846) [32,38], 1311 [32], 1312 [36], and 3052 [37] to study metal leaching. The US EPA method 3501A is a digestion method that uses nitric acid to extract analyte from sediments, sludges, soils, and oils. Meanwhile, US EPA method 3502 is also an extraction method that employs microwave-assisted acid digestion of siliceous matrices, and organic matrices and other complex matrices and is not appropriate for regulatory applications that require the use of leachate preparations as stated in method 3501A. Standard methods for leaching tests are the US EPA toxicity characteristic leaching procedure (TCLP-1311) and the synthetic precipitation leaching procedure (SPLP-1312). Detection of heavy metals can be done via inductively coupled plasma optical emission spectroscopy (ICP-OES), inductively coupled plasma-mass spectrometry (ICP-MS) and atomic absorption spectrophotometry (AAS) $[39,40]$. 'ICP-OES' is generally used for total 
dissolved solids (TDS) or suspended solids. 'ICP-MS' cannot be used to measure arsenic, mercury, and some other toxic metals with very low regulatory limits.

Cho et al. studied the leaching property of a single heavy metal, mercury $(\mathrm{Hg})$ (method 3501A and TCLP-1311) from FA, BA, sludge, and phosphor powder generated from municipal waste incinerators in Korea [32]. The ranges of $\mathrm{Hg}$ content were 11,847 to $23,795 \mu \mathrm{g} / \mathrm{Kg}$ (FA) and 8 to $521 \mu \mathrm{g} / \mathrm{Kg}$ (BA) (method 3501A). The concentrations of leached $\mathrm{Hg}$ from municipal waste incinerators were 0.8 to $242.9 \mu \mathrm{g} / \mathrm{L}$ (FA) and 0.1 to $0.7 \mu \mathrm{g} / \mathrm{L}$ (BA) [32].

Roessler et al. presented the leaching of total ammonia nitrogen (TAN) (SPLP-1312) posed by the ammoniated coal FA. The TAN concentrations released from leaching test exceeded $0.02 \mathrm{mg}$ TAN/L (US EPA) [36]. The classification was made into three groups: group $\mathrm{A}$ (low $\left.\mathrm{NH}_{3}\right)$, $\mathrm{B}$ (high $\left.\mathrm{NH}_{3}\right)$ and $\mathrm{C}(50 \%$ group $\mathrm{A}+50 \%$ group $\mathrm{B})$. The percentages of TAN were $58 \%$ (0.15 mg TAN/L), 66\% (8.55 mg TAN/L), and 65\% (3.61 mg TAN/L) for group A, B, and C accordingly [36].

Mokhtar et al. studied selected trace element behaviour in a coal-fired power plant in Malaysia for the assessment of abatement technologies for air pollution control (method 3052) [37]. The leached elements and heavy metals were As: $<7.0 \mathrm{mg} / \mathrm{L}$ (not detected), Be: 1.4-3.7 mg/L, cadmium (Cd): $<0.3 \mathrm{mg} / \mathrm{L}$ (not detected), $\mathrm{Cr}:<1 \mathrm{mg} / \mathrm{L}$ (not detected), $\mathrm{Cl}$ : $95.29 \mathrm{mg} / \mathrm{L}, \mathrm{F}: 56 \mathrm{mg} / \mathrm{L}, \mathrm{Hg}:<0.01 \mathrm{mg} / \mathrm{L}$ (not detected), Ni: $48.4 \mathrm{mg} / \mathrm{L}, \mathrm{Pb}:<2 \mathrm{mg} / \mathrm{L}$ (not detected) and Se: $<6 \mathrm{mg} / \mathrm{L}$ (not detected) [37].

Flues et al. [34], Hosseini et al. [33], Komonweeraket et al. [31], and Xiang et al. [35] presented leached heavy metal content based on different approaches. Flues et al. [34] studied speciation of heavy metals in coal and ashes (method 3501A-SW 846) at their origin pH (coal: pH 5.3, BA: 9.9, cyclone ash (Cyc): 12.1, bag ash (Bag): pH 11.9) from Figueira coal power plant, Brazil. The cyclone and bag ashes were FA type. Flues et al. used liquid extraction with an organic solvent, ethylenediaminetetraacetic acid (EDTA), for their sample. The percentages of leached heavy metals were $>70 \%$ for As, $>55 \%$ for Mo and the remaining were 30 to $50 \%$ for $\mathrm{Mn}, \mathrm{Zn}, \mathrm{Cd}$, and $\mathrm{Pb}$ [34].

Hosseini et al. studied the leaching properties of weathered Victorian brown coal fly ash upon $\mathrm{pH}$ changes (using ammonium chloride and hydrochloric acid) and durations from 30 to $60 \mathrm{~min}$. The leached concentrations of $\mathrm{Ca}$ and $\mathrm{Mg}$ ranged from $70 \%(\mathrm{pH} 3.0)$ to $85 \%(\mathrm{pH} 0.5)$ while other heavy metals leached from $15 \%(\mathrm{pH} 3.0)$ to $70 \%(\mathrm{pH} 0.5)$ [33].

Komonweeraket et al. studied leaching characteristics of heavy metals from coal fly ash mixed soils based on modified leaching test ( $\mathrm{pH}$ static test) under the influence of $\mathrm{pH}$ ( $\mathrm{pH} 1.5$ to 13) and detection was done using ICP-OES [31]. The ranges of heavy metal concentrations were from 12 ( $\mathrm{pH} 11.7$ ) to $80 \mathrm{mg} / \mathrm{L}$ ( $\mathrm{pH} 10.4)(\mathrm{As}), 575(\mathrm{pH} 10.4)$ to $3621 \mathrm{mg} / \mathrm{L}$ (pH 12.4) (Barium, Ba), 14,960 ( $\mathrm{pH}$ 6.1) to 246,300 mg/L (pH 12.4) (Ca), 0.4 (pH 6.1) to $1.29 \mathrm{mg} / \mathrm{L}(\mathrm{pH} 8.1)(\mathrm{Cd}), 3290(\mathrm{pH} 11.7)$ to $24,650 \mathrm{mg} / \mathrm{L}(\mathrm{pH} 12.4)(\mathrm{Mg})$, 2.1 (pH 10.4) to $39 \mathrm{mg} / \mathrm{L}$ (pH 6.1) (Selenium, Se) and 968 (pH 11.7) to $1622 \mathrm{mg} / \mathrm{L}$ (pH 12.4) (Strontium, Sr). At pH 6.6, 8.1, and 9.5, Sr and Ba were not detected [31].

Xiang et al. reported on leached heavy metals upon modified leaching test (column leaching test at four different $\mathrm{pH}$ values, leaching time: 7 days) and detection via ICP-MS. The concentrations of leached heavy metals were high. They were 89.56 to $222.2 \mathrm{mg} / \mathrm{L}$ (Li), 2.17 to 5.46 (Be), 5415 to $6919 \mathrm{mg} / \mathrm{L}$ (Ti), 85 to $105.30 \mathrm{mg} / \mathrm{L}$ (Cr), 176.6 to $447.5 \mathrm{mg} / \mathrm{L}$ (Mn), 25.21 to $38.70 \mathrm{mg} / \mathrm{L}(\mathrm{Ni}), 44.49$ to $67.68 \mathrm{mg} / \mathrm{L}(\mathrm{Cu}), 37.09$ to $107.10 \mathrm{mg} / \mathrm{L}$ (Zn), 0.07 to $0.66 \mathrm{mg} / \mathrm{L}(\mathrm{Cd}), 19.37$ to $68.29 \mathrm{mg} / \mathrm{L}(\mathrm{Pb}), 291.7$ to $309.5 \mathrm{mg} / \mathrm{L}$ (As), and 7.6 to $8.6 \mathrm{mg} / \mathrm{L}$ (Hg) [35].

Chen et al. did speciation studies of heavy metals in horizontal flue ash with direct measurement using ICP-OES after digestion with nitric acid similar to US EPA method 3501A. The heavy metals ranged from 31.09 to $90.20 \mathrm{mg} / \mathrm{L}$ (As), 34.12 to $250.32 \mathrm{mg} / \mathrm{L}$ (Cd), 138.09 to $548.42 \mathrm{mg} / \mathrm{L}(\mathrm{Cr}), 1004.68$ to $1530.25 \mathrm{mg} / \mathrm{L}(\mathrm{Cu}), 32.80$ to $375.62 \mathrm{mg} / \mathrm{L}(\mathrm{Ni}), 446.69$ to $2341.17 \mathrm{mg} / \mathrm{L}(\mathrm{Pb})$, and 4336.82 to $7322.16 \mathrm{mg} / \mathrm{L}(\mathrm{Zn})$ [35].

Regardless of standard procedures of leaching test, acid or microwave digestion methods, or liquid extraction method of heavy metals, most studies do not present ecological 
risk assessment in their findings [31-37]. However, Chen et al. reported ecological risk assessment of heavy metals from municipal waste, FA [38]. The extraction of heavy metals was based on nitric acid digestion method (method 3501A) and quantification by ICP-OES. As a result, the study obtained a huge concentration of heavy metals (i.e., cadmium $(\mathrm{Cd})$, chromium (Cr), nickel (Ni), $\mathrm{Pb}, \mathrm{Cu}, \mathrm{Zn}$ and 'As') ranging from 116 to $6470 \mathrm{mg} / \mathrm{kg}$ with high ecological risk index $(9937$ to 75,678$)$. The purpose of ecological risk assessment is to assess the impact of the leached material into aquatic environment. However, different perspectives can be seen as they reflect the ecological risk assessment of the total heavy metal contents from the raw material itself.

In statistical modelling, regression is a method used to estimate the strength and character of a relationship between dependent and one or more independent variables. In the current research, the Box-Behnken model was used to simulate ecological risk assessment and model risk indicators (ERI) based on four heavy metals that are commonly found in $\mathrm{CA}$, namely lead $(\mathrm{Pb})$, zinc $(\mathrm{Zn})$, copper $(\mathrm{Cu})$ and arsenic $(\mathrm{As})$ collected from a Malaysian power plant. The regression equation will be useful for aquatic environment monitoring purpose specifically focusing on heavy metals of coal ash. These models will benefit civil engineers, the scientific community, and local authorities in the future, particularly for the integration of coal ash as cement replacement in concrete for construction industries.

\section{Methodology}

\subsection{Ecological Risk Assessment}

The description of the CA samples, sampling location, standard method of leaching test and the quantification of leached heavy metals were described in Beddu et al. [4] and Abd Manan et al. [41]. The ecological risk assessment was conducted following the Håkanson method [42] for risk estimation of heavy metals pollution in sediments to aquatic organisms. The same method was applied by Effendi et al. [43] and Yi et al. [44]. The contamination factor $\left(C_{f}^{i}\right)$ (Equation (1)), the monomial potential ecological factor (Equation (2)) and potential ecological risk index (Equation (3)) are shown below:

$$
C_{f}^{i}=\frac{C_{o}^{i}}{C_{n}^{i}}
$$

$C_{o}^{i}=$ Concentration of heavy metal in $\mathrm{mg} / \mathrm{Kg}$

$C_{n}^{i}=$ Reference value for metals

$$
E_{r}^{i}=T_{r}^{i} \times C_{f}^{i}
$$

$E_{r}^{i}=$ Monomial potential ecological factor (i.e., one heavy metal only)

$T_{r}^{i}=$ Toxic response factor for a given substance

$$
R_{I}=\sum E_{r}^{i}
$$

$R_{I}=$ Risk Index

The reference for ecological risk assessment of heavy metals is shown in Table 1. It has reference value for metals and toxic response factors for $\mathrm{Pb}, \mathrm{Zn}, \mathrm{Cu}$ and $\mathrm{As}$ [45] and interpretation of risk index values for heavy metals contamination in sediments. 
Table 1. Reference for ecological risk assessment of heavy metals.

\begin{tabular}{|c|c|c|c|c|c|}
\hline \multicolumn{6}{|c|}{ Reference Value for Metals and Toxic Response Factors ( $\mathrm{Pb}, \mathrm{Zn}, \mathrm{Cu}$ and As) } \\
\hline & Heavy Metals & $\mathbf{P b}$ & $\mathrm{Zn}$ & $\mathrm{Cu}$ & As \\
\hline & $C_{n}^{i}$ & 25 & 80 & 30 & 15 \\
\hline & $T_{r}^{i}$ & 5 & 1 & 5 & 10 \\
\hline \multicolumn{6}{|c|}{ Interpretation of Risk Index Values [45] } \\
\hline$E_{r}^{i}$ & $\begin{array}{l}\text { Ecological risk of single } \\
\text { regulator }\end{array}$ & & & \multicolumn{2}{|c|}{ Total ecological risk } \\
\hline$E_{r}^{i}<40$ & Low potential ecological risk & & & \multicolumn{2}{|c|}{$\begin{array}{c}\text { Low ecological risk fo } \\
\text { the lake/basin }\end{array}$} \\
\hline $40 \leq E_{r}^{i}<80$ & $\begin{array}{c}\text { Moderate potential ecological } \\
\text { risk }\end{array}$ & $95 \leq$ & $<190$ & \multicolumn{2}{|c|}{$\begin{array}{l}\text { Moderate ecological } \\
\text { risk for the lake/basin }\end{array}$} \\
\hline $80 \leq E_{r}^{i}<160$ & $\begin{array}{l}\text { Considerable potential } \\
\text { ecological risk }\end{array}$ & 190 & & \multicolumn{2}{|c|}{$\begin{array}{c}\text { Considerable } \\
\text { ecological risk for the } \\
\text { lake/basin }\end{array}$} \\
\hline $160 \leq E_{r}^{i}<320$ & High potential ecological risk & \multirow{2}{*}{\multicolumn{2}{|c|}{$R_{I} \geq 380$}} & \multirow{2}{*}{\multicolumn{2}{|c|}{$\begin{array}{l}\text { Very high ecological } \\
\text { risk for the lake/basin }\end{array}$}} \\
\hline$E_{r}^{i} \geq 320$ & $\begin{array}{c}\text { Very high ecological risk at } \\
\text { hand for the substance in } \\
\text { question }\end{array}$ & & & & \\
\hline
\end{tabular}

\subsection{Model Equation for Ecological Risk Indicators}

Box-Behnken design with second order polynomial equation (Equation (4)) was employed using the Design Expert ${ }^{\circledR}$ software (Version 12) to establish the relationship between process variables namely heavy metals concentrations (i.e., $\mathrm{Pb}, \mathrm{Zn}, \mathrm{Cu}$ and $\mathrm{As}$ ) that leached from coal ash and the response variable, ERI.

$$
Y=\beta_{0}+\sum_{i=1}^{k} \beta_{i} \cdot x_{i}+\sum_{i=1}^{k} \beta_{i i} \cdot x_{i}^{2}+\ldots+\sum_{i \leq j}^{k} \sum_{j}^{k} \beta_{i j} \cdot x_{i} \cdot x_{i i}+\ldots+e
$$

$Y=$ Predicted response variable (Ecological Risk Index)

$\beta=$ Regression coefficient

$x_{i}=$ Linear term for variable $1(\mathrm{~Pb})$

$x_{i i}=$ Linear term for variable $2(\mathrm{Zn})$

$x_{i i i}=$ Linear term for variable $3(\mathrm{Cu})$

$x_{i v}=$ Linear term for variable $4(A s)$

$x_{i}{ }^{2}=$ Nonlinear squared term for variable $1(\mathrm{~Pb})$

$x_{i i}{ }^{2}=$ Nonlinear squared term for variable $2(\mathrm{Zn})$

$x_{i i i}{ }^{2}=$ Nonlinear squared term for variable $3(\mathrm{Cu})$

$x_{i v}{ }^{2}=$ Nonlinear squared term for variable $4(A s)$

$x_{i} \cdot x_{i i}=$ Interaction term for variable $1(\mathrm{~Pb})$ and variable $2(\mathrm{Zn})$

$x_{i} \cdot x_{i i i}=$ Interaction term for variable $1(\mathrm{~Pb})$ and variable $3(\mathrm{Cu})$

$x_{i} \cdot x_{i v}=$ Interaction term for variable $1(\mathrm{~Pb})$ and variable $4(\mathrm{As})$

$x_{i i} \cdot x_{i i i}=$ Interaction term for variable $2(\mathrm{Zn})$ and variable $3(\mathrm{Cu})$

$x_{i i} \cdot x_{i v}=$ Interaction term for variable $2(\mathrm{Zn})$ and variable $4(\mathrm{As})$

$x_{i i i} \cdot x_{i v}=$ Interaction term for variable $3(\mathrm{Cu})$ and variable $4(\mathrm{As})$

$k=$ Number of factors or process variables in the experiment

$e=$ Random error

The ranges of process variables and code factors are shown in Table S1. The values of the coded factors (i.e., low $(-1)$ and high $(+1)$ coded factors) in Table 2 were calculated based on Equation (5). The range is the difference between highest and lowest values 
(Equation (6)). The error percentage between experimental and predicted values was evaluated using Equation (7).

$$
\begin{gathered}
\text { Coded }=\frac{2 \times(\text { Actual setting }- \text { Average actual setting })}{(\text { Range between low and high actual settings })} \\
\text { Range }=\text { Highest value }- \text { Lowest value } \\
\text { Error }(\%)=\left|\frac{\text { Experimental Model }- \text { Predicted Model }}{\text { Experimental Model }} \times 100 \%\right|
\end{gathered}
$$

\begin{tabular}{|c|c|c|c|c|c|c|}
\hline \multirow{2}{*}{\multicolumn{2}{|c|}{$\begin{array}{c}\text { Ecological Risk Assessment of } \\
\text { Heavy Metals }\end{array}$}} & \multicolumn{4}{|c|}{$E_{r}^{i}$} & \multirow{2}{*}{$R_{I}$ (Observed) } \\
\hline & & $\mathrm{Pb}$ & $\mathrm{Zn}$ & $\mathrm{Cu}$ & As & \\
\hline \multirow{3}{*}{ TCLP } & FA & $1.80 \times 10^{-1}$ & $2.70 \times 10^{-3}$ & $4.70 \times 10^{-3}$ & $10.08 \times 10^{0}$ & $10.27 \times 10^{0}$ \\
\hline & BA & $1.35 \times 10^{-1}$ & $1.90 \times 10^{-3}$ & $4.50 \times 10^{-3}$ & $9.77 \times 10^{0}$ & $9.91 \times 10^{0}$ \\
\hline & $\mathrm{FA}+\mathrm{BA}$ & $2.05 \times 10^{-1}$ & $2.50 \times 10^{-3}$ & $5.50 \times 10^{-3}$ & $12.36 \times 10^{0}$ & $12.58 \times 10^{0}$ \\
\hline \multirow{3}{*}{ SPLP } & FA & $1.81 \times 10^{-1}$ & $2.70 \times 10^{-3}$ & $5.00 \times 10^{-3}$ & $10.15 \times 10^{0}$ & $10.34 \times 10^{0}$ \\
\hline & BA & $1.36 \times 10^{-1}$ & $1.90 \times 10^{-3}$ & $4.70 \times 10^{-3}$ & $9.76 \times 10^{0}$ & $9.90 \times 10^{0}$ \\
\hline & $\mathrm{FA}+\mathrm{BA}$ & $2.02 \times 10^{-1}$ & $2.40 \times 10^{-3}$ & $5.50 \times 10^{-3}$ & $12.40 \times 10^{0}$ & $12.61 \times 10^{0}$ \\
\hline
\end{tabular}

Table 2. Ecological risk index (ERI) of coal ash from Malaysian coal power plant.

\section{Results and Discussion}

\subsection{Ecological Risk Assessment}

The ecological risk assessment of coal ash from a coal power plant in Malaysia is shown in Table 2. The $R_{I}$ values for TCLP were $10.27 \times 10^{0}(\mathrm{FA}), 9.91 \times 10^{0}(\mathrm{BA})$ and $12.58 \times 10^{0}(\mathrm{FA}+\mathrm{BA})$; whereas $R_{I}$ for SPLP were $10.34 \times 10^{0}(\mathrm{FA}), 9.90 \times 10^{0}(\mathrm{BA})$ and $12.61 \times 10^{0}(\mathrm{FA}+\mathrm{BA})$. As shown in Table 3 [45], all values of $E_{r}^{i}$ and $R_{I}$ obtained in this study were less than 40 and 95 respectively, suggesting low risk to aquatic organisms.

Our ecological risk assessment aimed to evaluate and characterize risk posed by an actuator of environmental stressors (e.g., physical, biological, and chemical pollutants, introduction or infestation of invasive alien species, effects from forestry and land use, waterborne diseases, and global climate change) towards aquatic organisms $[27,46]$.

Heavy metals are hazardous upon continuous exposure and highly toxic even at low concentrations [9,47-49]. The natural concentration of heavy metals in fresh water $(\mathrm{mg} / \mathrm{L})$ has been reported to be $0.4 \mathrm{mg} / \mathrm{L}(\mathrm{As}), 0.2 \mathrm{mg} / \mathrm{L}(\mathrm{Cd}), 0.2 \mathrm{mg} / \mathrm{L}(\mathrm{Cr}), 10 \mathrm{mg} / \mathrm{L}(\mathrm{Cu})$, $0.08 \mathrm{mg} / \mathrm{L}(\mathrm{Hg}), 5 \mathrm{mg} / \mathrm{L}(\mathrm{Pb})$, and $10 \mathrm{mg} / \mathrm{L}(\mathrm{Zn})$ [42] (Table 3). The current research presents the ecological risk assessment of leached heavy metals $(\mathrm{Pb}, \mathrm{Cu}, \mathrm{Zn}$, and $\mathrm{As})$ from coal ash (i.e., FA, BA, and FA + BA) via standard procedure of leaching tests (method TCLP-1311 and SPLP-1312) that has shown the potential for the application in concrete technology due to its pozzolanic property $[4,41]$. The $\mathrm{Pb}, \mathrm{Cu}, \mathrm{Zn}$ and 'As' are major trace elements commonly found in coal ash. The concentrations of leached heavy metals ranged from 0.673 to $1.026 \mathrm{mg} / \mathrm{L}(\mathrm{Pb}), 0.027$ to $0.033 \mathrm{mg} / \mathrm{L}(\mathrm{Cu}), 0.149$ to $0.219(\mathrm{Zn})$, and 14.636 to $18.605 \mathrm{mg} / \mathrm{L}$ (As) [4,41] (Table 3). As is a water-soluble heavy metal [50] and was observed to leach the most. Nevertheless, the 'As' concentrations were still below the permissible limit of hazardous waste criteria. The concentrations of $\mathrm{Pb}, \mathrm{Cu}, \mathrm{Zn}$ and As were below the permissible limits by US EPA ( $\mathrm{Pb}$ and As) [51] and obeys the limits for industrial effluent (Standard A and Standard B) [52] and national drinking water quality standards (Zn and $\mathrm{Cu}$ ) [53]. Most of all, the concentrations were comparable to the natural concentrations of traces of heavy metals in freshwater [42]. The ranges of ecological risk assessment obtained and presented in the current study were from $9.91 \times 10^{0}$ to $12.58 \times 10^{0}$ (TCLP) and from $9.90 \times 10^{0}$ to $12.61 \times 10^{0}$ (SPLP). The ecological risk assessement was equal to low ecologocal risk for the lake/basin. 
Table 3. Comparison of concentrations of heavy metals in natural freshwater and current research.

\begin{tabular}{|c|c|c|c|c|c|c|c|}
\hline \multirow[b]{2}{*}{$\begin{array}{c}\text { Heavy } \\
\text { Metals (Ref.) }\end{array}$} & \multirow[b]{2}{*}{$\begin{array}{l}\text { Natural Con- } \\
\text { centration in } \\
\text { Fresh Water } \\
(\mathrm{mg} / \mathrm{L})[42]\end{array}$} & \multirow[b]{2}{*}{$\begin{array}{l}\text { Preindustrial } \\
\text { Reference } \\
\text { Value for } \\
\text { Lake } \\
\text { Sediments } \\
\text { (mg/L) [42] }\end{array}$} & \multicolumn{5}{|c|}{ This Research } \\
\hline & & & $\begin{array}{c}\text { Concentration } \\
\text { of Leached } \\
\text { Heavy } \\
\text { Metals from } \\
\text { Coal Ash } \\
\text { Via TCLP } \\
\text { and SPLP } \\
\text { (mg/L) }[4,41]\end{array}$ & $\begin{array}{c}\text { Monomial } \\
\text { Potential } \\
\text { Ecological } \\
\text { Factor (i.e., } \\
\text { One Heavy } \\
\text { Metal Only) } \\
\quad\left(E_{r}^{i}\right)\end{array}$ & $\begin{array}{l}\text { Ecological } \\
\text { Risk of } \\
\text { Single } \\
\text { Regulator }\end{array}$ & $\begin{array}{l}\text { Ecological } \\
\text { Risk Index } \\
\qquad\left(R_{I}\right)\end{array}$ & $\begin{array}{c}\text { Ecological } \\
\text { Risk } \\
\text { Assessment } \\
\text { of Heavy } \\
\text { Metals }\end{array}$ \\
\hline As & 0.4 & 15 & $\begin{array}{l}14.636- \\
18.605\end{array}$ & $9.76-12.40$ & \multirow{7}{*}{$\begin{array}{c}\text { Low } \\
\text { potential } \\
\text { ecological } \\
\text { risk } E_{r}^{i}<40\end{array}$} & \multirow{7}{*}{$9.90-12.61$} & \multirow{7}{*}{$\begin{array}{l}\text { Low } \\
\text { ecological } \\
\text { risk for the } \\
\text { lake/basin } \\
R_{I}<95\end{array}$} \\
\hline $\mathrm{Cd}$ & 0.2 & 1.0 & n.a. & n.a. & & & \\
\hline $\mathrm{Cr}$ & 0.2 & 90 & n.a. & n.a. & & & \\
\hline $\mathrm{Cu}$ & 10 & 50 & $0.027-0.033$ & $4.70-5.50$ & & & \\
\hline $\mathrm{Hg}$ & 0.08 & 0.25 & n.a. & n.a. & & & \\
\hline $\mathrm{Pb}$ & 5 & 70 & $0.673-1.026$ & $1.36-2.05$ & & & \\
\hline $\mathrm{Zn}$ & 10 & 175 & $0.149-0.219$ & $1.90-2.70$ & & & \\
\hline
\end{tabular}

Nevertheless, the importance of following standard methods has been emphasized by Abd Manan et al. (2021) showing comparison studies with inconsistencies of datasets due to modification of normal standard methods (e.g., modification duration and $\mathrm{pH}$ of leaching test). Thus, the term chemical speciation is preferable. The term 'leaching studies' for any modified leaching test must be avoided to prevent confusion with the existing standards.

\subsection{Model Equation for Ecological Risk Indicators}

The 29 combinations of four independent variables, in accordance with Box-Behnken design (Table S2), were used to compute the corresponding values of the dependent variable. The independent variables were leached heavy metal concentrations. The ranges were from $0.5 \mathrm{mg} / \mathrm{L}$ to $2.0 \mathrm{mg} / \mathrm{L}(\mathrm{Pb}), 0.05 \mathrm{mg} / \mathrm{L}$ to $0.30 \mathrm{mg} / \mathrm{L}(\mathrm{Zn}), 0.01 \mathrm{mg} / \mathrm{L}$ to $0.04 \mathrm{mg} / \mathrm{L}(\mathrm{Cu})$ and $13.00 \mathrm{mg} / \mathrm{L}$ to $19.00 \mathrm{mg} / \mathrm{L}(\mathrm{As})$. The dependent variable was ERI.

The analysis of variance (ANOVA) from the quadratic model for ERI is shown in Table 4. Sum of squares (SS) is a sum of squared differences on the plots. It measures the difference between values of the dependent variables and their mean values. Therefore, the data dispersion can be identified and the adequacy of the data for the regression analysis can be determined [54]. The mean square (MS) is the $S S$ divided by the degrees of freedom $(D F)$. The lower $S S$ and $M S$ values imply better model. The $S S$ and $M S$ values obtained were low equivalent to less than 0.5 implying admissible model.

The $F$ value, also called $F$-statistic (Fisher), evaluates the overall significance level of a regression model [55]. It is calculated by dividing the MS over residual mean [56]. The high $\mathrm{F}$ value shows large variability of group means as compared to the within group variability. As a result, the null hypothesis indicating group means are equal is rejected. The model $F$ value of $682,375.55$ implies that the model is significant. There was only a $0.01 \%$ chance that a model $F$ value this large could occur due to noise. The Prob $>F$ value is the probability for null hypothesis of the full model is true whereby coefficient of determination $\left(R^{2}\right)$ equals to zero. Values of Prob $>F$ less than 0.05 shows that the model terms are significant. Meanwhile, values of Prob $>F$ greater than 0.10 show that the model terms are not significant. Both values indicate 5 and 10 chances out of 100 accordingly for all of the regression parameters or $R^{2}$ in the model terms to be zero [55,57]. The indications of model terms based on Prob $>F$ value are shown below. 
Table 4. ANOVA for quadratic model.

\begin{tabular}{|c|c|c|c|c|c|c|c|}
\hline Scheme & SS & $\begin{array}{l}\text { Coefficient } \\
\text { Estimate }\end{array}$ & DF & MS & F Value & Prob $>$ F & Indication \\
\hline $\begin{array}{c}\text { Quadratic } \\
\text { Model }\end{array}$ & 0.4160 & 2.39 & 14 & 0.0297 & $682,375.55$ & $<0.0001$ & Significant \\
\hline $\mathrm{A}-\mathrm{Pb}$ & 0.0023 & 0.0139 & 1 & 0.0023 & $53,186.95$ & $<0.0001$ & Significant \\
\hline $\mathrm{B}-\mathrm{Zn}$ & $2.513 \times 10^{-7}$ & 0.0001 & 1 & $2.513 \times 10^{-7}$ & 5.77 & 0.0307 & Significant \\
\hline $\mathrm{C}-\mathrm{Cu}$ & $6.433 \times 10^{-7}$ & 0.0002 & 1 & $6.433 \times 10^{-7}$ & 14.77 & 0.0018 & Significant \\
\hline D-As & 0.4116 & 0.1852 & 1 & 0.4116 & $9,452,514.58$ & $<0.0001$ & Significant \\
\hline $\mathrm{AB}$ & $1.544 \times 10^{-11}$ & $-1.965 \times 10^{-6}$ & 1 & $1.544 \times 10^{-11}$ & 0.0004 & 0.9852 & Not significant \\
\hline AC & $3.953 \times 10^{-11}$ & $-3.144 \times 10^{-6}$ & 1 & $3.953 \times 10^{-11}$ & 0.0009 & 0.9764 & Not significant \\
\hline $\mathrm{AD}$ & 0.0000 & -0.0026 & 1 & 0.0000 & 622.03 & $<0.0001$ & Significant \\
\hline $\mathrm{BC}$ & $4.330 \times 10^{-15}$ & $-3.274 \times 10^{-8}$ & 1 & $4.330 \times 10^{-15}$ & $9.944 \times 10^{-8}$ & 0.9998 & Not significant \\
\hline $\mathrm{BD}$ & $2.938 \times 10^{-9}$ & -0.0000 & 1 & $2.938 \times 10^{-9}$ & 0.0675 & 0.7988 & Not significant \\
\hline $\mathrm{CD}$ & $7.521 \times 10^{-9}$ & -0.0000 & 1 & $7.521 \times 10^{-9}$ & 0.1727 & 0.6840 & Not significant \\
\hline $\mathrm{A}^{2}$ & $6.185 \times 10^{-8}$ & -0.0001 & 1 & $6.185 \times 10^{-8}$ & 1.42 & 0.2532 & Not significant \\
\hline $\mathrm{B}^{2}$ & $1.795 \times 10^{-11}$ & $1.664 \times 10^{-6}$ & 1 & $1.795 \times 10^{-11}$ & 0.0004 & 0.9841 & Not significant \\
\hline$C^{2}$ & $1.759 \times 10^{-11}$ & $1.647 \times 10^{-6}$ & 1 & $1.759 \times 10^{-11}$ & 0.0004 & 0.9842 & Not significant \\
\hline $\mathrm{D}^{2}$ & 0.0019 & -0.0171 & 1 & 0.0019 & $43,323.12$ & $<0.0001$ & Significant \\
\hline Residual & $6.096 \times 10^{-7}$ & & 14 & $4.354 \times 10^{-8}$ & & & \\
\hline Lack of Fit & $6.096 \times 10^{-7}$ & & 10 & $6.096 \times 10^{-8}$ & & & \\
\hline Pure Error & 0.0000 & & 4 & 0.000 & & & \\
\hline
\end{tabular}

The $\beta$ coefficient or standardized regression coefficient of determination $\left(R^{2}\right)$ for quadratic model and model terms for coded factors are; 2.39 (y-intercept), 0.0139 (A), $0.0001(\mathrm{~B}), 0.0002(\mathrm{C}), 0.1852(\mathrm{D}),-1.965 \times 10^{-6}(\mathrm{AB}),-3.144 \times 10^{-6}(\mathrm{AC}),-0.0026(\mathrm{AD})$, $-3.274 \times 10^{-8}(\mathrm{BC}),-0.0000(\mathrm{BD}),-0.0000(\mathrm{CD}),-0.0001\left(\mathrm{~A}^{2}\right), 1.664 \times 10^{-6}\left(\mathrm{~B}^{2}\right)$, $1.647 \times 10^{-6}\left(\mathrm{C}^{2}\right)$, and $-0.0171\left(\mathrm{D}^{2}\right)$. The $\beta$ coefficient for quadratic model and model terms for actual factors are; 0.870324 (y-intercept), $0.037472(\mathrm{~A}), 0.002303$ (B), 0.030839 (C), $0.12385(\mathrm{D}),-2.1 \times 10^{-5}(\mathrm{AB}),-2.79 \times 10^{-4}(\mathrm{AC}),-1.16 \times 10^{-3}(\mathrm{AD})$, $-1.7 \times 10^{-5}(\mathrm{BC}),-7.2 \times 10^{-5}(\mathrm{BD}),-9.64 \times 10^{-4}(\mathrm{CD}),-1.74 \times 10^{-4}\left(\mathrm{~A}^{2}\right)$, $1.06 \times 10^{-4}\left(\mathrm{~B}^{2}\right), 7.32 \times 10^{-3}\left(\mathrm{C}^{2}\right)$, and $-1.90 \times 10^{-3}\left(\mathrm{D}^{2}\right)$. Quadratic model and model terms $A, B, C, D, A D$, and $D^{2}$ for both coded and actual factors are significant ( $p$-value $\left.<0.05\right)$ (Table 4). The significant regression parameters of predictive models in terms of coded and actual factors are shown in Equations (8) and (9) accordingly. The $\beta$ coefficient for quadratic model and model terms of coded and actual factors are shown in Figure 1. The calculation of coded factors is shown in Table S3.

$$
\ln (E R I)=2.39+0.0139 A+0.0001 B+0.0002 C+0.1852 D-0.0026 A D-0.0171 D^{2}
$$

$$
\ln (E R I)=0.870324+0.037472 A+0.002303 B+0.030839 C+0.123850 D-0.001157 A D-0.001895 D^{2}
$$




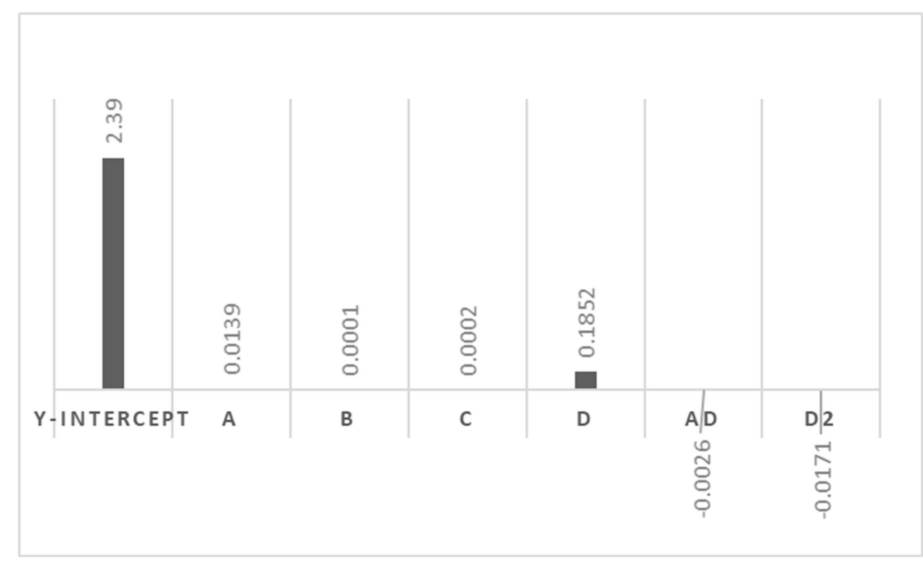

(a) Coded Factors

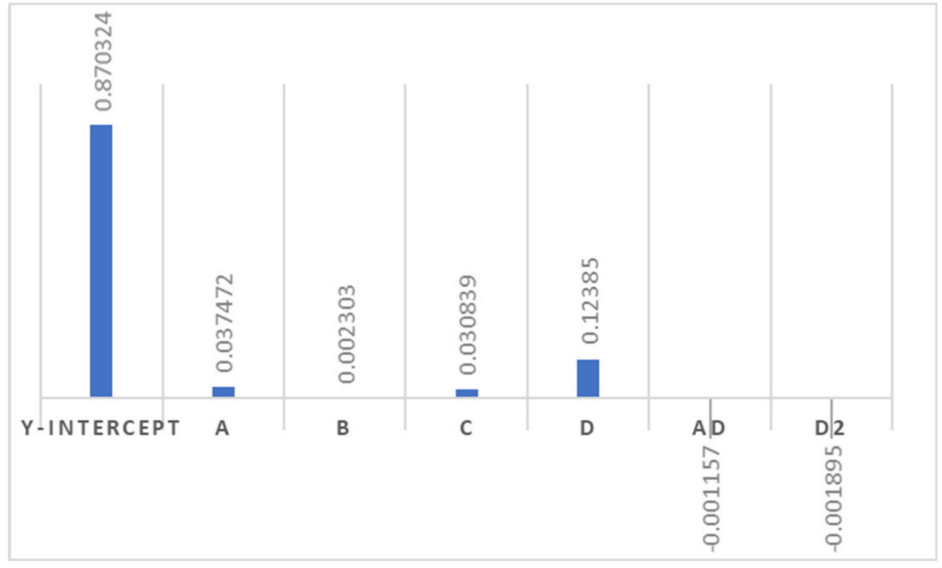

(b) Actual Factors

Figure 1. The $\beta$ coefficient for quadratic model and model terms of (a) coded and (b) actual factors.

Overall, the quadratic model is significant. The $R^{2}$ coefficient indicates the ratio of sum of squares due to regression (SSR) to total sum of squares (SST). It shows goodness of fit between one variable and another variable. Generally, a higher coefficient close to 1 indicates a good fit for the model (Table S4). The Adj. $R^{2}$ increases only if the new term improves the model more than would be expected by chance. The Adj. $R^{2}$ can be negative and will always be less than or equal to $R^{2}$. $R^{2}$ values smaller than 0.75 usually indicate an insufficient description of the experimental data by the model [58].

The patterns of predicted versus actual values plot for ERI are shown in Figure S1. There was no outlier observed and scatterplots were in a straight line showing a linear relationship between predicted against actual values plot. Therefore, the proposed model terms were sufficient, and constant variance assumption was verified.

Figure 2 shows the three-dimensional plots of $\mathrm{Pb}$, As and ERI. ERI of below 9 was a combination of $\mathrm{Pb}$ and 'As' at 0.5 to 1.4 and 13 to 13.4 respectively. ERI of 9 up to 12 has a consistent range of $\mathrm{Pb}$ equal to 0.5 to 2 . Apparently, As plays an important role as the main contributor to ERI. The ERI ranges from 9 to 10,10 to 11 and 11 to 12 have As in the range of 13.4 to $14.8,14.8$ to 16.4 and 16.4 to 17.8 accordingly. The ERI values of 12 and above were for 17.8 to 19 of As. The relationship of As (13 to 19) is in direction perpendicular to ERI ranging from 9 to 12 for both plots. The $\mathrm{Zn}(0.05$ to 0.3$)$ and $\mathrm{Cu}(0.01$ to 0.04$)$ have uniform values for all ascending ERI ranges (12.2 to 12.4). 


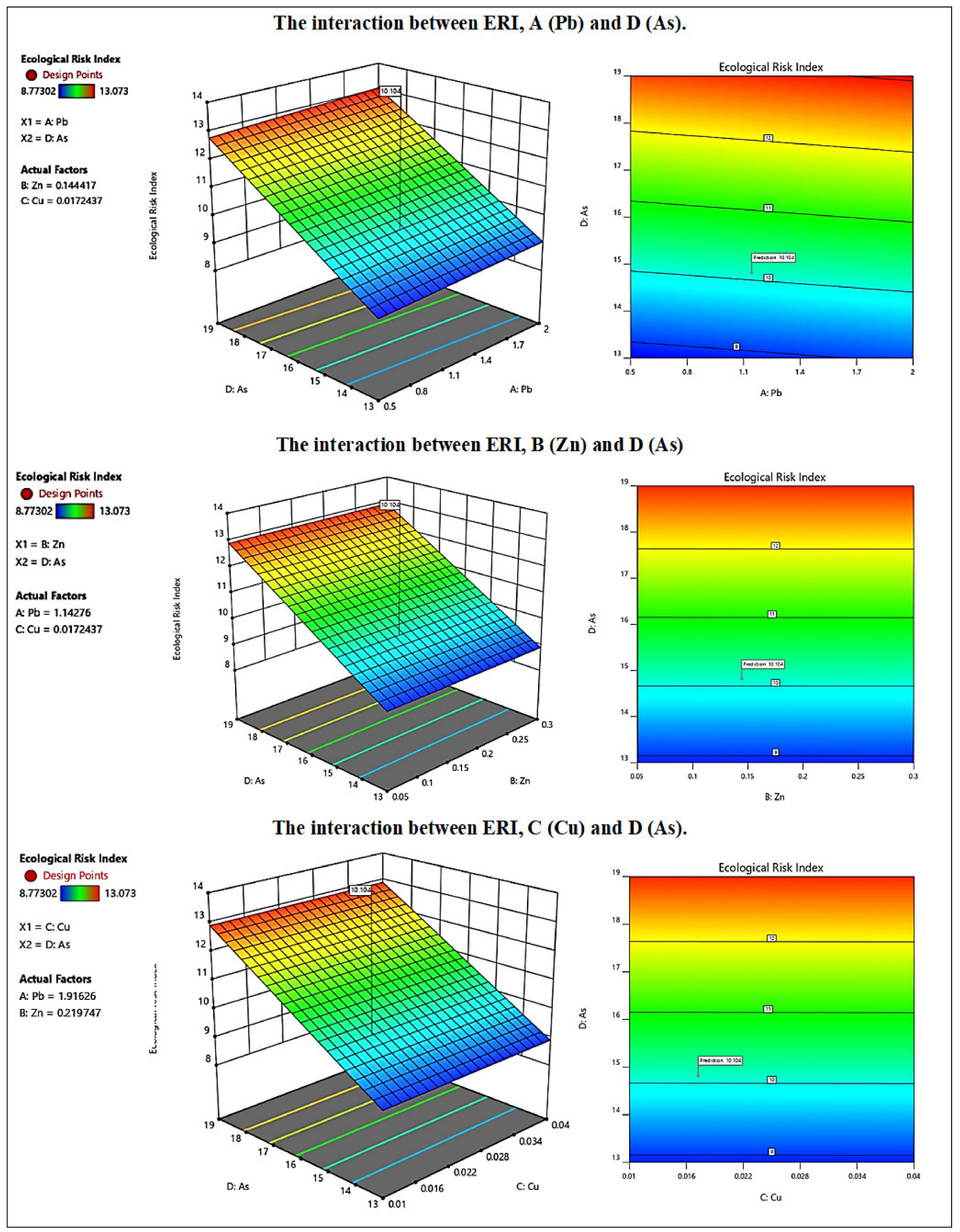

Figure 2. The interaction between ERI and heavy metals ( $\mathrm{Pb}$ vs. As, $\mathrm{Zn}$ vs. $\mathrm{As}, \mathrm{Cu}$ vs. As). 
ERI of below 12.2 was from 0.5 to 0.8 for $\mathrm{Pb}$. The ERI range from 12.2 to 12.3 was from 0.8 to 1.3 for $\mathrm{Pb}$. The ERI range from 12.3 to 12.4 ranged from 1.3 to 1.8 for $\mathrm{Pb}$. ERI value more than 12.4 was of 1.8 and more for $\mathrm{Pb}$. $\mathrm{Zn}(0.05$ to 0.3$)$ and $\mathrm{Cu}(0.01$ to 0.04$)$ have uniform values for all ascending ERI ranges (12.2 to 12.4). A cross pattern was observed at each ascended ERI. ERI below 12.19 has $\mathrm{Cu}<0.022$ and $\mathrm{Zn}<0.2$. The ERI ranging from 12.19 to 1.129 has $0.022>\mathrm{Cu}>0.034$ and $0.2>\mathrm{Zn}>0.3$. The ERI ranging from 12.192 to 12.194 has $\mathrm{Cu}>0.04$ and $\mathrm{Zn}>0.3$. The calculation and validation of optimized model is shown in Table S5 and Table S6.

$\mathrm{CA}$ is a sustainable supply for numerous innovative applications [1,12,14-22,59]. The reuse of CA as cement replacement material has been practiced in the US construction industries for decades $[23,24]$ due to its pozzolanic property $[3,10,11,26]$. Waste management need to be strategized at much lower risk posed to the environment (i.e., water, air, soil, plants, and animals) and human health [3].

This study is important for the prediction of ecological risk assessment of leached heavy metals from coal ash application in construction industries promoting sustainable supply for concrete technology $[2,26,60]$. The error percentages of coded and actual factors ranged from 0.14 to $0.32 \%$ and 0.01 to $0.15 \%$ accordingly. The optimized model risk indicators (ERI) (Equations (8) and (9)) are sufficient for this purpose and validated with error percentage of less than $5 \%[15,57]$.

\section{Conclusions}

This study focused on identifying the desired values of independent variables how the ecological risk of single regulators, namely $\mathrm{Pb}, \mathrm{Cu}, \mathrm{Zn}$ and $\mathrm{As}$, can achieve the sustainable material goals. The responses known as ecological risk index of each heavy metal were regressed by the multiple independent variables using a polynomial quadratic equation. The ecological risk assessment values $\left(E_{r}^{i}<40\right.$ and $\left.R_{I}<95\right)$ of coal ash (i.e., FA, BA and $\mathrm{FA}+\mathrm{BA}$ ) showed low risk to aquatic organisms showing potential application of FA and BA as cement replacement material. The established model risk indicator (ERI) (coded and actual factors) of $\mathrm{Pb}, \mathrm{Cu}, \mathrm{Zn}$ and As showed significant model terms perfectly fit to the corresponding ERI (sum of squares $=0.4160$, F value $=682,375.55$ ) with probability of $0.01 \%$ for an F-value could occur due to noise. The optimized ERI models were validated with error percentage of less than 5\%. The established model risk indicators will be beneficial for ecological risk assessment of coal ash application in the construction industry.

\section{Recommendation}

Industrial areas of the coal mining [61,62], forestry [63], oil, and gas industries [61,62] are exposed to anthropogenic metal enrichment in soil, air, and snow. The ecological risk assessment of leached heavy metals from CA is specific to the aquatic environment. Nevertheless, risk assessment of human, topsoil and/or sediment, air, and snow as presented in [61-63] could be performed using the application of a similar approach. Other than heavy metals, polycyclic aromatic hydrocarbons [61] could be another indicator for risk assessment of CA.

Supplementary Materials: The following are available online at https:/ /www.mdpi.com/article/10 .3390 / su131810222/s1, Figure S1: Predicted vs. actual values plot for ERI, Table S1: Process variables and code factors, Table S2: Box-Behnken design and responses results, Table S3: The calculation of coded factors, Table S4: Fit summary results for response parameters, Table S5: Calculation for the validation of the models, Table S6: Validation of optimised model.

Author Contributions: Conceptualization, S.B.; methodology, A.M. and D.D.; software, T.S.B.A.M.; validation, F.M.N., M.F.K.M.Y. and S.P.; formal analysis, T.K. and H.J.; investigation, N.L.M.K.; resources, D.M. and Z.I.; writing-original draft preparation, S.B. and T.S.B.A.M.; writing-review and editing, W.H.M.W.M., A.A. and N.W.R.; supervision, S.B.; project administration, S.B.; funding acquisition, S.B. and Z.I. All authors have read and agreed to the published version of the manuscript. 
Funding: The authors are thankful to Universiti Tenaga Nasional (UNITEN), Malaysia (J5100D4103BOLDRefresh2025-Centre of Excellence; J510050002-BOLDRefresh2025-Centre of Excellence; J510050002/2021012; U-TG-RD-20-23) and Ministry of Higher Education (FRGS/1/2020//TKO/ UNITEN//02/18) for the financial supports for this study. The work of Denys Dutykh has been supported by the French National Research Agency, through the Investments for Future Program (ref. ANR-18-EURE-0016-Solar Academy).

Institutional Review Board Statement: Not applicable.

Informed Consent Statement: Not applicable.

Data Availability Statement: Not applicable.

Acknowledgments: Authors would like to thank Mohamed Hasnain Isa from Universiti Teknologi Brunei; Marzuki Bin Ismail from Institute of Tropical Biodiversity and Sustainable Development, Universiti Malaysia Terengganu; Malay Chaudhuri (ret.) and Associate Nasiman Bin Sapari (ret.) from Civil and Environmental Engineering Department, Universiti Teknologi PETRONAS (UTP); Mahyun Binti Mohd Zainoodin, Siti Nabihah Binti Sadon and Muhammad Nur Hafiz Bin Mohd Saadon (CE094616), from College of Engineering, UNITEN; Yusyawati Binti Yahaya from Centralized analytical laboratory, UTP (yusyawati@utp.edu.my), Johan Ariff Bin Mohamed, Norhayama Binti Ramli, Zaaba Bin Mohammad, Khairul Anuar Bin Jamaluddin and Meor Asniwan Bin Mew Ghazali from Lab Services and Facilities Unit, UTP for the technical supports. In addition, this research pays honor to late Ismail Bin Abustan from the Civil Engineering Department, Universiti Sains Malaysia and late Associate Amirhossein Malakahmad from the Civil and Environmental Engineering Department, UTP.

Conflicts of Interest: The authors declare no conflict of interest.

\section{References}

1. Kumari, A.; Parween, R.; Chakravarty, S.; Parmar, K.; Pathak, D.D.; Lee, J.C.; Jha, M.K. Novel approach to recover rare earth metals (REMs) from Indian coal bottom ash. Hydrometallurgy 2019, 187, 1-7. [CrossRef]

2. Mohd Kamal, N.L.; Beddu, S.; Syamsir, A.; Mohammad, D.; Itam, Z.; Hamid, Z.A.A.; Manan, T.S.A. Immobilization of heavy metals for building materials in the construction industry-An overview. In Proceedings of the 6th International Conference on Recent Advances in Materials, Minerals \& Environment (RAMM) 2018, Penang, Malaysia, 27-29 November 2018; Elsevier Ltd.: Amsterdam, The Netherlands, 2018; 17, pp. 787-791.

3. European Parliament and Council European. Directive 2008/98/EC on waste (Waste Framework Directive)-EnvironmentEuropean Commission. Off. J. Eur. Union 2008, 312, 3-30.

4. $\quad$ Beddu, S.; Abd Manan, T.S.B.; Zainoodin, M.M.; Khan, T.; Wan Mohtar, W.H.M.; Nurika, O.; Jusoh, H.; Yavari, S.; Kamal, N.L.M.; Ghanim, A.A.; et al. Dataset on leaching properties of coal ashes from Malaysian coal power plant. Data Br. 2020, $31,105843$. [CrossRef] [PubMed]

5. Khan, T.; Mustafa, M.R.U.; Isa, M.H.; Manan, T.S.B.A.; Ho, Y.C.; Lim, J.W.; Yusof, N.Z. Artificial Neural Network (ANN) for Modelling Adsorption of Lead (Pb (II)) from Aqueous Solution. Water Air. Soil Pollut. 2017, 228, 1-15. [CrossRef]

6. Vyšvařil, M.; Bayer, P. Immobilization of Heavy Metals in Natural Zeolite-blended Cement Pastes. In Proceedings of the Ecology and New Building Materials and Products 2016, Cerna Hora, Czech Republic, 31 May-2 June 2016; Volume 151, pp. 162-169.

7. Magurran, A.E.; Khachonpisitsak, S.; Ahmad, A.B. Biological diversity of fish communities: Pattern and process. J. Fish Biol. 2011, 79, 1393-1412. [CrossRef] [PubMed]

8. Malakahmad, A.; Law, M.X.; Ng, K.-W.; Manan, T.S.A. The Fate and Toxicity Assessment of Polycyclic Aromatic Hydrocarbons (PAHs) in Water Streams of Malaysia. In Proceedings of the 4th International Conference on Process Engineering and Advanced Materials, Kuala Lumpur, Malaysia, 15-17 August 2016.

9. Malakahmad, A.; Manan, T.S.B.A.; Sivapalan, S.; Khan, T. Genotoxicity assessment of raw and treated water samples using Allium cepa assay: Evidence from Perak River, Malaysia. Environ. Sci. Pollut. Res. 2018, 25, 5421-5436. [CrossRef]

10. Sajwan, K.S.; Punshon, T.; Seaman, J.C. Production of Coal Combustion Products and Their Potential Uses. In Coal Combustion Byproducts and Environmental Issues; Springer: Berlin/Heidelberg, Germany, 2006; pp. 3-9.

11. Asokan, P.; Saxena, M.; Asolekar, S.R. Coal combustion residues-Environmental implications and recycling potentials. Resour. Conserv. Recycl. 2005, 43, 239-262. [CrossRef]

12. Almahayni, T.; Vanhoudt, N. Does leaching of naturally occurring radionuclides from roadway pavements stabilised with coal fly ash have negative impacts on groundwater quality and human health? J. Hazard. Mater. 2018, 349, 128-134. [CrossRef] [PubMed]

13. Wang, N.; Sun, X.; Zhao, Q.; Wang, P. Treatment of polymer-flooding wastewater by a modified coal fly ash-catalysed Fenton-like process with microwave pre-enhancement: System parameters, kinetics, and proposed mechanism. Chem. Eng. J. 2021, 406, 126734. [CrossRef] 
14. Valeev, D.; Kunilova, I.; Shoppert, A.; Salazar-Concha, C.; Kondratiev, A. High-pressure HCl leaching of coal ash to extract Al into a chloride solution with further use as a coagulant for water treatment. J. Clean. Prod. 2020, 276, 123206. [CrossRef]

15. Kamal, N.L.M.; Shafiq, N.; Alaloul, W.S.; Beddu, S.; Abd Manan, T.S.B. Application of Response Surface Methodology for the Optimization of Mix Design Concrete Using Coal Bottom Ash as Cement Replacement Material. Lect. Notes Civ. Eng. 2021, 132, 396-404.

16. Akanyeti, İ.; Damdelen, Ö.; Anvarov, A. Geo-polymerization technique for brick production from coal ash and cigarette butts. J. Mater. Res. Technol. 2020, 9, 12855-12868. [CrossRef]

17. Lieberman, R.N.; Knop, Y.; Izquierdo, M.; Palmerola, N.M.; de la Rosa, J.; Cohen, H.; Muñoz-Quirós, C.; Cordoba, P.; Querol, X. Potential of hazardous waste encapsulation in concrete with coal fly ash and bivalve shells. J. Clean. Prod. 2018, 185, 870-881. [CrossRef]

18. Guo, C.; Zhao, L.; Yang, J.; Wang, K.; Zou, J. A novel perspective process for alumina extraction from coal fly ash via potassium pyrosulfate calcination activation method. J. Clean. Prod. 2020, 271, 122703. [CrossRef]

19. Scott, C.; Kolker, A. FS 2019-3048: Rare Earth Elements in Coal and Coal Fly Ash; U.S. Geological Survey: Reston, VA, USA, 2019.

20. Pan, J.; Nie, T.; Vaziri Hassas, B.; Rezaee, M.; Wen, Z.; Zhou, C. Recovery of rare earth elements from coal fly ash by integrated physical separation and acid leaching. Chemosphere 2020, 248, 126112. [CrossRef] [PubMed]

21. Su, H.F.; Tan, F.; Lin, J.F. An integrated approach combines hydrothermal chemical and biological treatment to enhance recycle of rare metals from coal fly ash. Chem. Eng. J. 2020, 395, 124640. [CrossRef]

22. King, J.F.; Taggart, R.K.; Smith, R.C.; Hower, J.C.; Hsu-Kim, H. Aqueous acid and alkaline extraction of rare earth elements from coal combustion ash. Int. J. Coal Geol. 2018, 195, 75-83. [CrossRef]

23. US Department of Transportation Introduction. User Guidelines for Waste and Byproduct Materials in Pavement Construction; FHWA-RD-97-148; Federal Highway Administration: Washington, DC, USA, 2016.

24. Conner, J.R. Chemical Fixation and Solidification of Hazardous Wastes; Van Nostrand Reinhold: New York, USA, 2006.

25. Nwaichi, E.O.; Dhankher, O.P. Heavy Metals Contaminated Environments and the Road Map with Phytoremediation. J. Environ. Prot. (Irvine Calif.) 2016, 07, 41-51. [CrossRef]

26. Itam, Z.; Kamal, N.L.M.; Syamsir, A.; Beddu, S.; Muhammad, D.; Zahari, N.M.; Kai, L.M.; Hamid, Z.A.A.; Razak, N.A. Extraction of iron from coal bottom ash by carbon reduction method. AIP Conf. Proc. 2018, 2030, 020261.

27. Abd Manan, T.S.B.; Khan, T.; Wan Mohtar, W.H.M.; Beddu, S.; Qazi, S.; Sheikh Khozani, Z.; Mohd Kamal, N.L.; Sarwono, A.; Jusoh, H.; Yavari, S.; et al. Ecological and Health Risk Assessment of Polycyclic Aromatic Hydrocarbons (PAHs) in Sungai Perak, Malaysia. J. Clean. Prod. 2021, 294, 126124. [CrossRef]

28. Neff, J.M.; Stout, S.A.; Gunster, D.G. Ecological risk assessment of polycyclic aromatic hydrocarbons in sediments: Identifying sources and ecological hazard. Integr. Environ. Assess. Manag. 2005, 1, 22-33. [CrossRef]

29. Hernández-Pedraza, M.; Caballero-Vázquez, J.A.; Peniche-Pérez, J.C.; Pérez-Legaspi, I.A.; Casas-Beltran, D.A.; Alvarado-Flores, J. Toxicity and Hazards of Biodegradable and Non-Biodegradable Sunscreens to Aquatic Life of Quintana Roo, Mexico. Sustainability 2020, 12, 3270. [CrossRef]

30. Crăciun, N.; Negrea, B.; Pop, C.E.; Jujea, V.; Stoian, G. Experimental research compared aquaculture of certain species of the Lemna genus with demonstration of environmental requirements and of the adaptations to environmental conditions specific to aquatic eutroph-polytroph ecosystems. Sci. Ann. Danube Delta Inst. 2020, 25, 2020.

31. Komonweeraket, K.; Cetin, B.; Benson, C.H.; Aydilek, A.H.; Edil, T.B. Leaching characteristics of toxic constituents from coal fly ash mixed soils under the influence of $\mathrm{pH}$. Waste Manag. 2015, 38, 174-184. [CrossRef]

32. Cho, J.H.; Eom, Y.; Park, J.M.; Lee, S.B.; Hong, J.H.; Lee, T.G. Mercury leaching characteristics of waste treatment residues generated from various sources in Korea. Waste Manag. 2013, 33, 1675-1681. [CrossRef] [PubMed]

33. Hosseini, T.; Han, B.; Selomulya, C.; Haque, N.; Zhang, L. Chemical and morphological changes of weathered Victorian brown coal fly ash and its leaching characteristic upon the leaching in ammonia chloride and hydrochloric acid. Hydrometallurgy 2015, 157, 22-32. [CrossRef]

34. Flues, M.; Sato, I.M.; Scapin, M.A.; Cotrim, M.E.B.; Camargo, I.M.C. Toxic elements mobility in coal and ashes of Figueira coal power plant, Brazil. Fuel 2013, 103, 430-436. [CrossRef]

35. Xiang, W.; Han, B.; Zhou, D.; Nzihou, A. Physicochemical properties and heavy metals leachability of fly ash from coal-fired power plant. Int. J. Min. Sci. Technol. 2012, 22, 405-409. [CrossRef]

36. Roessler, J.; Cheng, W.; Hayes, J.B.; Shou, L.; Ferraro, C.; Wu, C.Y.; Bergin, M.; Townsend, T.G. Evaluation of the leaching risk posed by the beneficial use of ammoniated coal fly ash. Fuel 2016, 184, 613-619. [CrossRef]

37. Mokhtar, M.M.; Taib, R.M.; Hassim, M.H. Understanding selected trace elements behavior in a coal-fired power plant in Malaysia for assessment of abatement technologies. J. Air Waste Manag. Assoc. 2014, 64, 867-878. [CrossRef]

38. Chen, L.; Liao, Y.; Ma, X.; Niu, Y. Effect of co-combusted sludge in waste incinerator on heavy metals chemical speciation and environmental risk of horizontal flue ash. Waste Manag. 2020, 102, 645-654. [CrossRef]

39. Meche, A.; Martins, M.C.; Lofrano, B.E.S.N.; Hardaway, C.J.; Merchant, M.; Verdade, L. Determination of heavy metals by inductively coupled plasma-optical emission spectrometry in fish from the Piracicaba River in Southern Brazil. Microchem. J. 2010, 94, 171-174. [CrossRef]

40. Lee, K.H.; Oshima, M.; Motomizu, S. Inductively coupled plasma mass spectrometric determination of heavy metals in sea-water samples after pre-treatment with a chelating resin disk by an on-line flow injection method. Analyst 2002, 127, 769-774. [CrossRef] 
41. Abd Manan, T.S.B.; Beddu, S.; Mohamad, D.; Mohd Kamal, N.L.; Wan Mohtar, W.H.M.; Khan, T.; Jusoh, H.; Sarwono, A.; Ali, M.M.; Che Muda, Z.; et al. Physicochemical and Leaching Properties of Coal Ashes from Malaysian Coal Power Plant. Chem. Phys. Lett. 2021, 769, 138420. [CrossRef]

42. Hakanson, L. An ecological risk index for aquatic pollution control.a sedimentological approach. Water Res. 1980, 14, 975-1001. [CrossRef]

43. Effendi, H.; Kawaroe, M.; Mursalin; Lestari, D.F. Ecological Risk Assessment of Heavy Metal Pollution in Surface Sediment of Mahakam Delta, East Kalimantan. Procedia Environ. Sci. 2016, 33, 574-582. [CrossRef]

44. Yi, Y.; Yang, Z.; Zhang, S. Ecological risk assessment of heavy metals in sediment and human health risk assessment of heavy metals in fishes in the middle and lower reaches of the Yangtze River basin. Environ. Pollut. 2011, 159, 2575-2585. [CrossRef] [PubMed]

45. Hilton, J.; Davison, W.; Ochsenbein, U. A mathematical model for analysis of sediment core data: Implications for enrichment factor calculations and trace-metal transport mechanisms. Chem. Geol. 1985, 48, 281-291. [CrossRef]

46. Chapman, P.M. Ecological Risk and Weight of Evidence Assessments. In Marine Ecotoxicology; Elsevier: Amsterdam, The Netherlands, 2016; pp. 257-271.

47. Abd Manan, T.S.B.; Beddu, S.; Khan, T.; Wan Mohtar, W.H.M.; Sarwono, A.; Jusoh, H.; Mohd Kamal, N.L.; Sivapalan, S.; Ghanim, A.A.J. Step by step procedures: Degradation of polycyclic aromatic hydrocarbons in potable water using photo-Fenton oxidation process. MethodsX 2019, 6, 1701-1705. [CrossRef]

48. Khan, T.; Abd Manan, T.S.B.; Isa, M.H.; Ghanim, A.A.J.; Beddu, S.; Jusoh, H.; Iqbal, M.S.; Ayele, G.T.; Jami, M.S. Modeling of $\mathrm{Cu}(\mathrm{II})$ adsorption from an aqueous solution using an Artificial Neural Network (ANN). Molecules 2020, 25, 3263. [CrossRef]

49. Malakahmad, A.; Abd Manan, T.S.; Sivapalan, S. Detection methods of carcinogens in estuaries: A review. Int. J. Sustain. Dev. Plan. 2015, 10, 601-619. [CrossRef]

50. Bajare, D.; Bumanis, G.; Upeniece, L. Coal combustion bottom ash as microfiller with pozzolanic properties for traditional concrete. In Proceedings of the Modern Building Materials, Structures and Techniques, Vilnius, Lithuania, 16-17 May 2013; Elsevier: Amsterdam, The Netherlands, 2013; Volume 57, pp. 149-158.

51. US EPA. Introduction to Hazardous Waste Identification (40 CFR Parts 261); Solid Waste and Emergency Response (5305W) EPA530K-05-012; United States Environmental Protection Agency: Washington, DC, USA, 2005.

52. Department of Environment Malaysia. Environmental Quality (Industrial Effluent) Regulations P.U.A_434-2009. Available online: https://www.doe.gov.my/portalv1/wp-content/uploads/2015/01/Environmental_Quality_Industrial_Effluent_ Regulations_2009_-_P.U.A_434-2009.pdf (accessed on 1 March 2021).

53. Department of Environment Malaysia. Annex National Water Quality Standards for Malaysia; Department of Environment Malaysia: Putrajaya, Malaysia, 2021.

54. Corporate Finance Institute Sum of Squares-Definition, Formulas, Regression Analysis. Available online: https: // corporatefinanceinstitute.com/resources/knowledge/other/sum-of-squares/ (accessed on 11 February 2021).

55. Ogee, A.; Ellis, M.; Scibilia, B.; Pammer, C. Understanding Analysis of Variance (ANOVA) and the F-Test. Available online: https:/ / blog.minitab.com/blog/adventures-in-statistics-2/understanding-analysis-of-variance-anova-and-the-f-test (accessed on 11 February 2021).

56. Frost, J. How to Interpret the F-Test of Overall Significance in Regression Analysis. Available online: https://statisticsbyjim.com/ regression/interpret-f-test-overall-significance-regression/ (accessed on 11 February 2021).

57. Abd Manan, T.S.B.; Khan, T.; Sivapalan, S.; Jusoh, H.; Sapari, N.; Sarwono, A.; Ramli, R.M.; Harimurti, S.; Beddu, S.; Sadon, S.N.; et al. Application of response surface methodology for the optimization of polycyclic aromatic hydrocarbons degradation from potable water using photo-Fenton oxidation process. Sci. Total Environ. 2019, 665, 196-212. [CrossRef] [PubMed]

58. Gauthier, T.D.; Hawley, M.E. Statistical Methods. In Introduction to Environmental Forensics, 3rd ed.; Elsevier: Amsterdam, The Netherlands, 2015; ISBN 9780124046962.

59. Wang, A.; Yin, H.; Ge, C.; Ren, M.; Liu, Y.; Jiang, T. Synthesis of hollow silver spheres using poly-(styrene-methyl acrylic acid) as templates in the presence of sodium polyacrylate. Appl. Surf. Sci. 2010, 256, 2611-2615. [CrossRef]

60. Mohamad, D.; Beddu, S.; Sadon, N.; Mohd Kamal, N.L.; Itam, Z.; Zainol, M.A.; Ramli, M.Z.; Sapuan, W.M. Properties of self-curing concrete containing bottom ash. Int. J. Adv. Appl. Sci. 2017, 4, 138-142. [CrossRef]

61. Walker, T.R. Comparison of anthropogenic metal deposition rates with excess soil loading from coal, oil and gas industries in the Usa River Basin, NW Russia. Pol. Polar Res. 2005, 26, 299-314.

62. Walker, T.R.; Young, S.D.; Crittenden, P.D.; Zhang, H. Anthropogenic metal enrichment of snow and soil in north-eastern European Russia. Environ. Pollut. 2003, 121, 11-21. [CrossRef]

63. Walker, T.R.; Crittenden, P.D.; Dauvalter, V.A.; Jones, V.; Kuhry, P.; Loskutova, O.; Mikkola, K.; Nikula, A.; Patova, E.; Ponomarev, V.I.; et al. Multiple indicators of human impacts on the environment in the Pechora Basin, north-eastern European Russia. Ecol. Indic. 2009, 9, 765-779. [CrossRef] 